\title{
Brazilian Protocol for Sexually Transmitted Infections, 2020: infections that cause genital ulcers
}

\author{
Mauro Cunha Ramos ${ }^{[1]}$, José Carlos Sardinha ${ }^{[2]}$, Herculano Duarte Ramos de Alencar ${ }^{[3]}$, \\ Mayra Gonçalves Aragón ${ }^{[4],[5]}$ and Leonor Henriette de Lannoy ${ }^{[4],[5]}$
}

\author{
[1]. Clínica Privada, Pesquisador Autônomo, Porto Alegre, RS, Brasil. \\ [2]. Fundação de Dermatologia Tropical e Venerologia Alfredo da Matta, Manaus, AM, Brasil. \\ [3]. Secretaria de Estado de Saúde de São Paulo, Programa Estadual de DST/Aids, São Paulo, SP, Brasil. \\ [4]. Ministério da Saúde, Secretaria de Vigilância em Saúde, Brasília, DF, Brasil. \\ [5]. Universidade Federal do Espírito Santo, Programa de Pós-Graduação em Doenças Infecciosas, Vitória, ES, Brasil.
}

\begin{abstract}
Infections that cause genital ulcers are one of the themes comprising the Clinical Protocol and Therapeutic Guidelines for Comprehensive Care for People with Sexually Transmitted Infections, published by the Brazilian Ministry of Health in 2020. The Protocol and Guidelines have been developed based on scientific evidence and validated in discussions with specialists. This article addresses clinical genital ulcer syndrome caused by sexually transmitted infections and its most common etiological agents: Treponema pallidum (syphilis), herpes simplex virus-2 (genital herpes) and herpes simplex virus-1 (perioral herpes), Haemophilus ducreyi (chancroid), Chlamydia trachomatis serotypes L1, L2 and L3 (lymphogranuloma venereum), and Klebsiella granulomatis (donovanosis). Epidemiological and clinical aspects of these infections and guidelines for their diagnosis and treatment are presented, including strategies for surveillance, prevention, and control actions to support health managers and professionals in the qualification of care.
\end{abstract}

Keywords: Syphilis. Chancre. Genital herpes. Chancroid. Lymphogranuloma venereum. Granuloma inguinale.

Highlighted excerpt: Approximately $70 \%$ of the genital ulcers attended in specialized clinics are due to sexually transmitted infections, particularly in adolescents and young adults.

\section{FOREWORD}

This article addresses the infections that cause genital ulcers, a subject that comprises the Clinical Protocol and Therapeutic Guidelines (PCDT) for Comprehensive Care for People with Sexually Transmitted Infections (STI), published by the Health Surveillance Secretariat of the Brazilian Ministry of Health in $2020^{1}$. To draft this document, a selection of available evidence was analyzed and discussed by a panel of specialists. The National Committee for Health Technology Incorporation in the Brazilian National Health System (Conitec) approved this document ${ }^{2}$.

\footnotetext{
Corresponding author: Leonor Henriette de Lannoy.

e-mail: leonordelannoy@gmail.com

(D) https://orcid.org/0000-0002-9520-8538

Received 01 February 2021

Accepted 10 March 2021
}

\section{EPIDEMIOLOGICAL ASPECTS}

Approximately $70 \%$ of the genital ulcers attended in specialized clinics are due to STI, particularly in adolescents and young adults ${ }^{3}$. As a syndrome, genital ulcers are not a compulsory reporting condition in Brazil, making it difficult to quantify their occurrence. They are, however, a frequent cause of consultations and are a significant cofactor for human immunodeficiency virus (HIV) transmission ${ }^{4}$. Genital ulcers can have different causes, such as other infections, trauma, inflammatory diseases (e.g., pemphigus, erythema multiforme, contact dermatitis, erosive lichen planus, or fixed drug eruption), and neoplastic lesions (e.g., squamous cell carcinoma or other neoplasms). The latter is particularly relevant in older adults and those with immunodepression ${ }^{1}$.

Establishing the etiologic agent on a clinical basis is difficult due to polymorphism in presentations ${ }^{5}$. The availability of accurate and rapid diagnostic tests varies according to different agents and different health systems scenarios. For this reason, the World Health Organization has recommended the syndromic treatment, adopted by several countries ${ }^{3,6,7}$.

The most common agent found in genital ulcers is the herpes simplex virus (HSV), type 1 (HSV-1) and type 2 (HSV-2). They are 
DNA viruses that belong to the Herpesviridae family ${ }^{8}$. The second most common agent is Treponema pallidum, which causes syphilis. These agents can also be found in association ${ }^{3,9}$. Brazil, similarly to other countries ${ }^{10}$, faces a significant increase in syphilis cases since 2017. In 2018, the government reported a detection rate of acquired syphilis of 75.8 cases per 100,000 inhabitants $^{10}$.

Chancroid is caused by Haemophilus ducreyi, a sexually transmitted Gram-negative bacterium. The condition, which occurs most frequently in men and in tropical regions ${ }^{1,11}$, has been significantly diminishing, possibly due to the syndromic approach introduction ${ }^{12}$. A systematic review carried out with publications from 1980 to 2014 revealed that after the year 2000, up to $15 \%$ of genital ulcers were chancroids, with 14 studies conducted in 13 countries $^{6}$. Since 2000, chancroid cases have been sporadic in Europe $^{11}$. In a Brazilian study at a specialized STI center in Manaus, no chancroid case was identified in 434 genital ulcers analyzed consecutively without prior selection?

Lymphogranuloma venereum is caused by Chlamydia trachomatis, the highly invasive serotypes L1, L2, and L3. Transmission is also attributed to asymptomatic people ${ }^{13,14}$. It is an endemic condition among men who have sex with men (MSM) in Europe, predominantly anogenital and rectal infections ${ }^{14}$. Lymphogranuloma venereum outbreaks in high-income countries and MSM (mainly by the L2b variant) have been associated with unprotected receptive anal exposure and HIV infection ${ }^{15}$. Sexual activity facilitated by global travel, online social networking, and pre-exposure prophylaxis of HIV infection is believed to have contributed to its reemergence ${ }^{15}$.

Donovanosis is caused by Klebsiella granulomatis, a sporadic condition most commonly found in countries with tropical and subtropical climates. Associated with sexual transmission, it has low transmissibility, and its transmission mechanisms are not well known ${ }^{16}$.

\section{CLINICAL ASPECTS}

The clinical aspects of genital ulcers are very varied and have low sensitivity and specificity regarding the etiological agent ${ }^{9}$. The diagnosis based on clinical impression showed positive predictive values of $30.9 \%$ for syphilis and $32.7 \%$ for chancroid, with no clinical correlation for cases with mixed chancre in Brazil ${ }^{9}$. Even so, the characteristics of genital ulcers should be evaluated and vary according to the etiological agent.

\section{Herpes simplex virus 1 and 2}

Infection caused by HSV-1 and HSV-2 sometimes presents a symptomatic primoinfection, which occurs with incubation of six days on average and a duration of approximately 20 days $^{8,17,18}$. It is characterized by numerous vesicles that evolve into painful, ulcerated lesions, whose bottoms are covered with a yellowish coating. These lesions are accompanied by general malaise, fever, myalgia, painful regional enlarged lymph nodes, and severe urinary symptoms, especially in women ${ }^{18}$.

Once the infection occurs, the virus is transported along the peripheral nerves' axons to sensitive ganglia. It enters latency, a state in which it can persist for life or suffer reactivations. Reactivated, the virus migrates to the mucous and cutaneous surfaces, again through the sensory nerves, and can be eliminated asymptomatically or cause episodes of recurrent lesions. The outbreaks, which may be the first manifestation, are spontaneous or induced by several factors (for example, exposure to ultraviolet radiation, infections, use of drugs, immunodeficiency, or physical or emotional stress). Recurrent manifestations are more frequent by HSV-2 than HSV- $1^{17}$. Most infected individuals will experience a recurrence in less than one year, and with each subsequent year, their intensity and average number decrease by about one event per year. These recurrences are lighter and last less. They are often preceded by prodromal symptoms such as itching, paresthesia, or pain at the site of lesions near the primoinfection area. Initially, they consist of vesicles of citrine content grouped in clusters on an erythematous base. The vesicles are rarely found in the mucous membranes because they rupture more quickly and originate polycyclic ulcers that regress spontaneously in approximately seven to ten days ${ }^{17,18}$.

\section{Syphilis}

Chronic affection transmitted by sexual contact, whether genital, anal, or oral, or even by vertical transmission ${ }^{1,19,20}$. It alternates periods of latency and clinical manifestations, often cutaneo-mucous lesions, and can affect any organ with transitory or definitive manifestations, depending on the organ affected ${ }^{13}$. The classic genital ulcer, called hard chancre, typically occurs as a single, painless ulcer with a clean bottom and an infiltrated base at the entrance site of T. pallidum $^{9,20}$. More common in genital organs, the ulcer can go unnoticed, especially when located in cavities such as the interior of the vagina, perianal and rectal regions, and oral cavity. The incubation period is from ten to 90 days, with an average of three weeks. The hard chancre disappears without scarring, with or without treatment, in approximately three to eight weeks. Increased regional lymph nodes typically accompany it, often unilateral, usually multiple, with one standing out for its larger size. They are painless, of elastic consistency, and nonsuppurative $\mathrm{e}^{19,20,21}$.

\section{Chancroid}

Very painful genital or perianal ulcers typically characterize soft chancre or Ducrey's chancre. It rarely occurs in the oral cavity or other regions of the tegument. It has an irregular border and unclean bottom, covered with a yellowish, necrotic, and fetid coating. When removed, it reveals friable granulation tissue and a non-infiltrated base. The most frequent locations in men are the frenulum and the balanoprepucial groove, and in women, the furcula and the inner face of the inner and outer lips ${ }^{12}$. Satellite lesions by autoinoculation are common, as well as disfiguring scars. It is accompanied by inguinal adenitis in $30 \%$ to $50 \%$ of cases, a unilateral inflammatory bubo that tends to fistulize through a single orifice. Tense and fluctuating lymph nodes can be relieved by needle aspiration. The drainage or excision of the affected lymph nodes is contraindicated. They may attack deep lymph node chains in the form of systemic disease ${ }^{11}$.

\section{Lymphogranuloma venereum}

It presents ulcers that usually go unnoticed by the infected person or the health professional. Its evolution occurs in three phases: inoculation, regional lymphatic dissemination, and sequelae. 
The inoculation phase starts with a papule, a pustule, or a small painless ulcer, which disappears without leaving sequelae. It may occur in the rectum and rarely in the urethra or cervix. Depending on its location, it may present mucopurulent exudate ${ }^{14,22}$. The regional lymphatic dissemination phase develops from one to six weeks after infection. Especially in women, the affected ganglia chain depends on the location of the initial lesion. In men, inguinal lymphadenopathy represents the main reason for consultation and is unilateral in $70 \%$ of cases ${ }^{14,22}$. In the last clinical phase of the condition, called the sequelae phase, ganglia's involvement evolves with a fusion of lymph nodes into a large mass, with liquefaction and fistulation by multiple holes. Orogenital contact can cause ulcerative glossitis with regional lymphadenopathy. It may be accompanied by proctitis or proctocolitis, sometimes simulating rectal cancer. The illness may be accompanied by general symptoms such as fever, malaise, anorexia, weight loss, arthralgia, night sweats, and meningism. In case of initial lesions in the cervix or rectovaginal pouch, lymphatic drainage is performed by pararectal ganglia, with permanent damage to the lymphatic network. The chronic lymphatic obstruction leads to genital elephantiasis, which in women is called esthiomene. Rectal, vaginal, or bladder fistulas may occur, as well as orificial stenosis, events that should always suggest the diagnosis of lymphogranuloma venereum ${ }^{14,22}$.

\section{Donovanosis}

The original lesion may vary in appearance. It can start with a flat edge ulcer that evolves to hypertrophic or vegetating ulcer, with granular bottom, single or multiple, well delimited, that grows slowly and progressively. It has a bright red aspect and easy bleeding to manipulation. There is a predilection for skin or mucous folds, with frequent "mirror configuration"23. Adenitis does not occur, but pseudobuboes may appear in the inguinal region (subcutaneous granulomatous nodules). Genital elephantiasis is a late sequel by obstructive lymphatic phenomena. The extragenital spread is rare and most often occurs from primary genital or perigenital lesions ${ }^{16,23}$. The differential diagnosis of donovanosis includes syphilis, chancroid, tuberculosis, and other granulomatous diseases, cutaneous amebiasis, ulcerated neoplasms, and American tegumentary leishmaniasis ${ }^{1,16}$.

\section{DIAGNOSIS}

The assistance to people with lesions presents particularities. The interview must be conducted in an environment of privacy, in an empathetic manner, and without value judgments, either through speech or non-verbal language. Inquiries about sexual practices and identification of STI risk factors, such as age under 30, history of new or multiple sexual partnerships (especially in the past three months), sexual partnerships with STI, prior or concurrent STI, and irregular condom use are required ${ }^{9,24,25}$. Psychoactive drugs, anonymous or group sexual encounters, professional sexual activity, sexual abuse, street situation, or liberty deprivation must be considered. Populations with difficult access to services, such as transexuals, deserve special attention.

The etiological diagnosis of genital ulcers based on anamnesis and physical examination can be imprecise; therefore, it is important to use diagnostic tests whenever they are available ${ }^{9,26}$. These tests only have value if the results are immediately available because treatment institution should not be postponed depending on the results.
These tests' sensitivity is variable due to technical particularities and relies on the number of pathogens in the sample obtained ${ }^{9,27}$.

\section{Herpes simplex virus $\mathrm{HSV}-1$ and $\mathrm{HSV}-2$}

Serological tests for HSV-1 and HSV-2 detections are available. Although they are of little help in diagnosis, identifying the viral type can help evaluate prognosis and counseling. It is estimated that HSV-2 has greater transmissibility, including transmission from the pregnant woman to the newborn ${ }^{9,24}$.

Viral culture, reserved for research environments and considered a gold standard exam, is being replaced by tests based on nucleic acid amplification test (NAAT), which have greater sensitivity and practicality ${ }^{26}$.

\section{Treponema pallidum}

Dark-field microscopy can allow the identification of spirochetes with characteristic shapes and movements. Lymph obtained by the expression is used, ideally without bleeding, which must be analyzed immediately. The use of material obtained from lesions of the oral cavity is inappropriate due to the presence of saprophytic spirochaetes unrelated to syphilis. Direct immunofluorescence or special stains require longer processing and will hardly be useful in clinical context. Identification of genital lesions indicates serological investigation for diagnostic clarification and screening of concomitant STI. There are two types of serological tests, treponemal and nontreponemal. Among the treponemal tests, the following can be mentioned: rapid tests by immunochromatography, treponemal fluorescent antibody-absorption (FTA-Abs), T. pallidum particle agglutination assay (TPHA), electrochemiluminescence, and the enzyme-linked immunosorbent assay (ELISA). Nontreponemal tests, such as the venereal disease research laboratory (VDRL) and rapid plasma reagin (RPR), have particular importance in the serological follow-up ${ }^{19,20,26}$. Treponemal tests become positive, on average, from one to three weeks from lesion onset, slightly earlier than nontreponemal tests. The rapid tests, distributed by the Ministry of Health, are practical, safe, and easy to perform by trained professionals. They provide results in up to 30 minutes and allow diagnostic support, decision making at the time of consultation, and immediate treatment ${ }^{27}$.

\section{Haemophilus ducreyi}

Smear microscopy of lesions with abundant exudate may allow identification of organized streptobacilli two by two, a configuration compared to "train tracks". This examination has much lower sensitivity and specificity than culture, a procedure with many demands and challenging performance. DNA amplification techniques, such as NAAT, are now considered the gold standard for detecting H. ducreyi, with sensitivity up to $98.4 \%$. Some kits for polymerase chain reaction (PCR) have the advantage of simultaneously testing other agents, such as T. pallidum and HSV $\mathrm{V}^{9,11,12,26}$.

\section{Chlamydia trachomatis}

NAAT tests, which include PCR and ligase chain reaction, are the recommended methods for detecting $C$. trachomatis in material collected from ulcer specimens, rectum, bubo aspirates, pharynx, 
biopsy specimens, and urine samples, which are little available in the routine. ${ }^{14,21,28}$ Serological tests are of little importance for the identification of C. trachomatis ${ }^{9,26}$.

\section{Klebsiella granulomatis}

The diagnosis is established by identifying Donovan bodies in the microscopy of tissue fragment smears or their anatomopathological study, stained by Giemsa, Leishman's, Wright's, or Rapi-Diff methods. It is a microorganism of difficult culture, and NAATs are available, especially in research institutions , $^{9,26,29}$.

\section{TREATMENT}

STIs are the main cause of genital ulcers and should invariably compose the diagnostic hypotheses, especially in the presence of epidemiological elements. Longer developing ulcers of more than four weeks in duration require a more careful evaluation since they may be related to neoplastic processes, chronic infectious diseases, or immunosuppression. Most of the time, these processes require specialized care, biopsy, and histopathological studies.

STIs' importance as a public health issue lies in their high frequency of occurrence and the need to interrupt transmission. The use of laboratory tests, although desirable, has limitations. In genital ulcers with STI suspicion, it is not acceptable to delay the treatment depending on laboratory test results. The use of combinations of therapeutic options to treat one or more agents is desirable in some scenarios s, $19,20,24,25,30^{\text {. }}$

Figure 1 presents guidelines for the management of infections that cause genital ulcers ${ }^{1}$. Due to the significant reduction in the incidence of chancroid $^{7}$, the lack of epidemiological surveillance of this condition $^{31}$ and the constant need to update the recommendations, the Ministry of Health instituted, in 2018, a project to identify the main etiological agents of genital ulcers

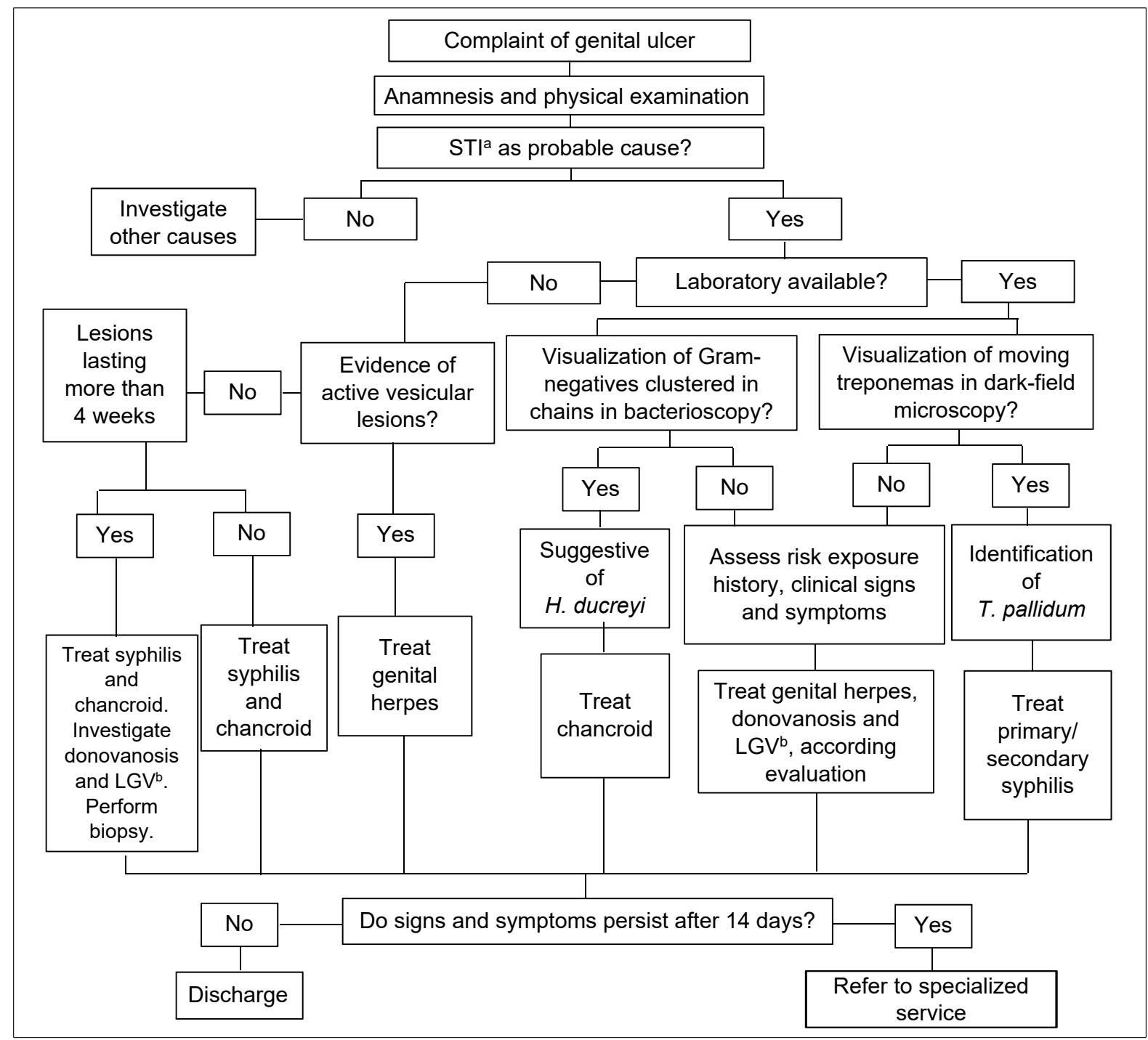

Source: adapted from the Clinical Protocol and Therapeutic Guidelines for Comprehensive Care for People with Sexually Transmitted Infections, 20201.

Notes: a) STI: sexually transmitted infections; b) LGV: lymphogranuloma venereum.

FIGURE 1: Recommendations for the management of genital ulcer infections. 
(HSV type 1 and 2, T. pallidum, and H. ducreyi) using molecular tests in specific services. This project's findings may modify the current conduct flowchart regarding genital ulcers, as was the case for urethral discharge syndrome $\mathrm{e}^{32,33}$.

During the evaluation of genital ulcer complaints, given evidence or history of characteristic vesicular lesions, the treatment of genital herpes is indicated. In case of first episode, acyclovir $200 \mathrm{mg}$, two pills, per os, three times a day, for seven to ten days, and, in the case of recurrence, acyclovir $200 \mathrm{mg}$, two tablets, per os, three times a day, for five days. In cases of need of genital herpes suppression (six or more episodes per year), acyclovir $200 \mathrm{mg}$, two pills, per os, twice a day, for up to six months, with the possibility of prolonging the treatment for up to two years.

For the treatment of other STI with genital ulcers and clinical pictures with less than four weeks of evolution, syphilis (hard chancre) must be treated with benzathine penicillin, a single dose of 2.4 million international units (IU), deep intramuscular (1.2 million IU in each gluteus), and chancroid with azithromycin $1 \mathrm{~g}$, single-dose, per os. In cases of lesions with more than four weeks of evolution, a biopsy must be performed. The institution of treatment for syphilis, chancroid, lymphogranuloma venereum, and donovanosis must be assessed. For lymphogranuloma venereum and donovanosis, more prolonged treatments are necessary. In the case of lymphogranuloma, doxycycline $100 \mathrm{mg}$ must be taken twice a day orally for 21 days as the first option, and azithromycin as an alternative. In the case of donovanosis, it is recommended to take azithromycin 500mg, two pills, per os, once a week, for at least three weeks or until the lesions heal, and, as an alternative treatment, the use of doxycycline, ciprofloxacin, or sulfamethoxazoletrimethoprim may be assessed ${ }^{1}$. The recommended treatments, including in special situations such as immunosuppression and pregnancy, are summarized in Figure 2 and Figure 3. It is important to emphasize that given a lesion with sudden evolution and a history of exposure to drugs, fixed drug eruption must be considered ${ }^{24,34}$.

\begin{tabular}{|c|c|c|}
\hline Clinical condition & Treatment & Remarks \\
\hline First incidence & $\begin{array}{l}\text { Aciclovira } 200 \mathrm{mg} \text {, two pills, per os (PO), } 3 \mathrm{x} / \text { day, for } \\
7-10 \text { days } \\
\text { or } \\
\text { aciclovir } 200 \mathrm{mg}, 1 \text { pill, PO, } 5 x / \text { day }(7 \mathrm{~h}, 11 \mathrm{~h}, 15 \mathrm{~h} \text {, } \\
19 \mathrm{~h}, 23 \mathrm{~h}) \text {, for } 7-10 \text { days }\end{array}$ & $\begin{array}{l}\text { Start the treatment as early as } \\
\text { possible. } \\
.{ }^{b} \\
\text { Treatment may be prolonged if } \\
\text { healing is incomplete after ten days } \\
\text { of therapy. }\end{array}$ \\
\hline Recurrence & $\begin{array}{l}\text { Aciclovira } 200 \mathrm{mg} \text {, two pills, } \mathrm{PO}, 3 x / \text { day, for five } \\
\text { days } \\
\text { or } \\
\begin{array}{l}\text { Acyclovira } 200 \mathrm{mg} \text {, four pills, PO, } 2 x / \text { day, for five } \\
\text { days }\end{array}\end{array}$ & $\begin{array}{l}\text { Treatment must be started } \\
\text { preferably in the prodromal period } \\
\text { (increased local sensitivity, burning, } \\
\text { pain, itching, and hyperemia of the } \\
\text { genital region). } \text {. }^{\mathrm{b}, \mathrm{c}}\end{array}$ \\
\hline Suppression of genital herpes (6 or more episodes/year) & $\begin{array}{l}\text { Acyclovira } 200 \mathrm{mg} \text {, two pills, PO, } 2 x / \text { day, for up to } \\
\text { six months, treatment may be extended for up to } \\
2 \text { years }\end{array}$ & $\begin{array}{l}\text { Individuals with repeated episodes } \\
\text { of genital herpes (more than } 6 \text { per } \\
\text { year) are considered eligible for } \\
\text { suppressive treatment. } \\
\text { Periodic assessment of renal and } \\
\text { hepatic function is indicated. }{ }^{b, c}\end{array}$ \\
\hline Genital herpes in immunosuppressed individuals & $\begin{array}{l}\text { Endovenous acyclovira }, 5-10 \mathrm{mg} / \mathrm{kg} \text { of weight, } \\
8 / 8 \mathrm{~h} \text {, for } 5 \text { to } 7 \text { days, or until clinical resolution }\end{array}$ & $\begin{array}{l}\text { In case of extensive lesions in } \\
\text { individuals with immunosuppression } \\
\text { (chronic users of corticosteroids, } \\
\text { people using immunomodulators, } \\
\text { individuals with transplanted solid } \\
\text { organs, and people living with } \\
\text { HIV), intravenous treatment can be } \\
\text { chosen. } \text {. }^{\mathrm{b}} \mathrm{C}\end{array}$ \\
\hline Gestation & \multicolumn{2}{|c|}{$\begin{array}{l}\text { Treat the first incidence in any quarter of the pregnancy, according to the treatment for the } \\
\text { first incidence. } \\
\text { If the first infection occurred during pregnancy or recurrences were frequent during the } \\
\text { gestational period, suppressive therapy might be performed, starting at } 36 \text { weeks, with } \\
\text { acyclovir } 400 \mathrm{mg}, 3 \times / \text { day. }\end{array}$} \\
\hline
\end{tabular}

Source: Clinical Protocol and Therapeutic Guidelines for Comprehensive Care for People with Sexually Transmitted Infections, 20201.

Notes: a) Treatment with antivirals is effective in reducing the intensity and duration of incidences when performed early; b) Local treatment can be done with compresses of physiological solution or a degerming aqueous solution to sanitize the lesions. Oral analgesics can be used if necessary. It is recommended to return within one week to reevaluate the lesions; c) The means of transmission, the possibility of asymptomatic infection, the fear of rejection by sexual partners, and concerns about the ability to have children are aspects that must be addressed. It is important to mention that there is no association between genital herpes and cancer. 


\begin{tabular}{|c|c|c|c|}
\hline Sexually transmitted infection & First option & Alternative & Remarks \\
\hline Syphilis (hard chancre) & $\begin{array}{l}\text { Benzathine benzylpenicillin } 2.4 \\
\text { million international units (IU), } \\
\text { intramuscular (IM), single-dose (1.2 } \\
\text { million IU in each gluteus) }\end{array}$ & $\begin{array}{l}\text { Doxycycline } 100 \mathrm{mg}, 12 / 12 \mathrm{~h} \text {, per os } \\
\text { (PO), for } 15 \text { days }\end{array}$ & $\begin{array}{l}\text { Treatment for recent syphilis: } \\
\text { primary, secondary, and recent } \\
\text { latent syphilis (with up to one year of } \\
\text { evolution). } \\
\text { If considered late syphilis: treat } \\
\text { with benzathine benzylpenicillin } 2.4 \\
\text { million IU, IM, weekly ( } 1.2 \text { million } \\
\text { IU in each gluteus), for three weeks } \\
\text { (total dose: } 7.2 \text { million IU, IM). } \\
\text { Alternative: doxycycline } 100 \mathrm{mg} \text {, } \\
\text { 12/12h, PO, for } 30 \text { days. }\end{array}$ \\
\hline Chancroid & $\begin{array}{l}\text { Azithromycin } 500 \mathrm{mg} \text {, two pills, } \mathrm{PO} \text {, a } \\
\text { single dose }\end{array}$ & $\begin{array}{l}\text { Ceftriaxone } 250 \mathrm{mg} \text {, IM, single dose } \\
\text { or } \\
\text { ciprofloxacin } 500 \mathrm{mg} \text {, one tablet, } \mathrm{PO} \text {, } \\
2 \mathrm{x} / \text { day, for three days }\end{array}$ & $\begin{array}{l}\text { Local hygiene measures must } \\
\text { accompany the systemic treatment. }\end{array}$ \\
\hline Lymphogranuloma venereum & $\begin{array}{l}\text { Doxycycline } 100 \mathrm{mg}, \mathrm{PO}, 1 \text { pill, } 2 \mathrm{x} / \\
\text { day, for } 21 \text { days }\end{array}$ & $\begin{array}{l}\text { Azithromycin } 500 \mathrm{mg} \text {, two pills, } \mathrm{PO} \text {, } \\
1 \mathrm{x} / \text { week, for } 21 \text { days (preferred for } \\
\text { pregnant women) }\end{array}$ & $\begin{array}{l}\text { The prolongation of therapy may be } \\
\text { necessary until the resolution of the } \\
\text { symptomatology. } \\
\text { The antibiotic therapy has no } \\
\text { significant effect on the duration } \\
\text { of inguinal lymphadenopathy, but } \\
\text { acute symptoms are often quickly } \\
\text { eradicated. } \\
\text { Antibiotics do not reverse sequelae } \\
\text { such as rectal stenosis or genital } \\
\text { elephantiasis. }\end{array}$ \\
\hline Donovanosis & $\begin{array}{l}\text { Azithromycin } 500 \mathrm{mg} \text {, two pills, } \mathrm{PO} \text {, } \\
1 \mathrm{x} / \text { week, for at least three weeks, or } \\
\text { until lesions heal }\end{array}$ & $\begin{array}{l}\text { Doxycycline } 100 \mathrm{mg} \text {, one tablet, } \mathrm{PO} \text {, } \\
2 \times / \text { day, for at least } 21 \text { days, or until } \\
\text { the complete disappearance of the } \\
\text { lesions } \\
\text { or } \\
\text { ciprofloxacin } 500 \mathrm{mg} \text {, one and } 1 / 2 \text { pill, } \\
\text { PO, } 2 \times / \text { day, for at least } 21 \text { days, or } \\
\text { until lesions heal (total dose: } 750 \mathrm{mg} \text { ) } \\
\text { or } \\
\text { sulfamethoxazole-trimethoprim } \\
\text { ( } 400 / 80 \mathrm{mg} \text { ), two pills, PO, } 2 x / \text { day, for } \\
\text { at least three weeks or until lesions } \\
\text { heal }\end{array}$ & $\begin{array}{l}\text { If there is no response to the } \\
\text { appearance of the lesion in the first } \\
\text { days of treatment with ciprofloxacin, } \\
\text { it is recommended to add an } \\
\text { aminoglycoside, such as gentamicin, } \\
1 \mathrm{mg} / \mathrm{kg} / \mathrm{day} \text {, intravenous, } 3 \mathrm{x} / \mathrm{day} \text {, } \\
\text { for at least three weeks, or until the } \\
\text { lesions heal. } \\
\text { For people living with HIV, the same } \\
\text { therapeutic schemes are suggested; } \\
\text { the use of parenteral therapy with } \\
\text { gentamicin should be considered in } \\
\text { the most severe cases. } \\
\text { The sequelae of tissue destruction } \\
\text { or lymphatic obstruction may require } \\
\text { surgical correction. }\end{array}$ \\
\hline
\end{tabular}

Source: adapted from the Clinical Protocol and Therapeutic Guidelines for Comprehensive Care of People with Sexually Transmitted Infections, $2020^{1}$ and CDC guidelines, $2015^{9}$.

Notes: a) Doxycycline is contraindicated for pregnant and lactating women; b) Ciprofloxacin is contraindicated for children and pregnant and lactating women.

FIGURE 3: Treatment of genital ulcers with a diagnosis of syphilis, chancroid, lymphogranuloma venereum, or donovanosis.

The sexual partners of the last three months must be oriented about exposure risks and evaluated and treated according to clinical, laboratory, or epidemiological findings $\mathrm{s}^{8,9,12,24,25}$. Sexual partners of individuals with syphilis whose exposure occurred up to 90 days before the onset of symptoms must be evaluated ${ }^{19,20}$, performing their presumptive treatment with a single dose penicillin benzathine 2.4 million IU, single-dose, intramuscular. Sexual partners of individuals with chancroid whose exposure occurred up to ten days before the onset of symptoms should be evaluated and treated with azithromycin 500mg, two pills, per os, single dose ${ }^{9,12}$. For asymptomatic partners of people with HSV-1 and HSV-2, presumptive treatment is not recommended ${ }^{8,31,35}$. Presumptive treatment of sexual partners of people with chlamydia, with exposure up to 60 days before the onset of symptoms is indicated ${ }^{9,14,22,28}$ with azithromycin 500mg, two pills, per os, single-dose, or doxycycline $100 \mathrm{mg}$, one tablet, per os, twice a day for seven days (contraindicated in pregnant women, nursing mothers and children under nine). In the case of donovanosis, presumptive treatment of asymptomatic sexual partners is not recommended because of low infectivity ${ }^{16,29}$.

\section{Surveillance, prevention, and control}

Counseling centered on the person and their sexual practices aim at recognizing riskier practices and establishing a risk reduction 
plan in light of combined prevention recommendations for STI, HIV, and viral hepatitis ${ }^{1}$. The use of barrier methods during oral, vaginal, and anal sexual activity must be indicated. Sexual accessories must be for individual use and sanitized before, and after use ${ }^{1,9}$. HIV infection prophylaxis on post-exposure or pre-exposure must be offered when indicated ${ }^{1}$.

Rapid testing for HIV, syphilis, and hepatitis B and C infection must invariably be recommended. Post-therapeutic serological follow-up tests are indicated for people with syphilis. Vaccination for HPV and hepatitis A and B prophylaxis should follow the recommendations ${ }^{9,24,25}$. NAAT screening for $C$. trachomatis and Neisseria gonorrhoeae infections in urine samples, urethral or cervical exudate is recommended, despite its unavailability in most services ${ }^{1}$.

Syphilis cases with ulcers that present a reagent test (treponemal or nontreponemal) must be compulsorily reported as acquired syphilis ${ }^{31}$, and partners will only be notified after investigation, depending on the test results and the presence of symptoms, as defined in the case definition of acquired syphilis ${ }^{1}$.

\section{SPECIAL POPULATIONS}

\section{Pregnant women}

Genital ulcers caused by STI deserve careful attention due to the potential for vertical transmission of some etiological agents, especially T. pallidum. The suspicion of syphilis in pregnant woman indicates treatment according to the clinical stage, in a mandatory way, independently of laboratory results. Post-treatment nontreponemal tests must be performed every 30 days ${ }^{9,19,20}$. HSV also presents specificities in its management during pregnancy. Its occurrence at the end of pregnancy increases the risk of fetal and neonatal complications. In the presence of active lesions in the genital area, a cesarean section is indicated ${ }^{8,36,37}$. The occurrence of adverse events in pregnancy due to chancroid and donovanosis is rare ${ }^{9}$. In the case of donovanosis, there are reports of perinatal transmission cases involving the otorhinolaryngological structures of the newborn ${ }^{38-40}$.

\section{People with HIV infection}

STI treatment regimens are the same as those recommended for people without HIV infection. Genital ulcers facilitate HIV transmission, increasing the importance of early treatment, and the higher risk is especially significant for genital herpes, syphilis, and chancroid ${ }^{9,23,24}$. Syphilis coinfection can alter the clinical course of this condition, with atypical and aggressive manifestations ${ }^{19,20}$. In HSV coinfection, lesions can be more painful, atypical, and longer-lasting and may require intravenous medication to control the symptoms ${ }^{8,35}$. Chancroid and lymphogranuloma venereum must be carefully monitored since they may need more prolonged treatment due to greater chance of response delay or therapeutic failure ${ }^{14,21,27}$.

\section{ORCID}

Mauro Cunha Ramos - 0000-0003-4341-2390

José Carlos Sardinha - 0000-0003-2177-0904

Herculano Duarte Ramos de Alencar - 0000-0002-9834-6135

Mayra Gonçalves Aragón - 0000-0001-6631-1790

Leonor Henriette de Lannoy - 0000-0002-9520-8538

\section{ACKNOWLEDGEMENTS}

The authors thank the technical group of specialists responsible for elaborating the Clinical Protocol and Therapeutic Guidelines for Comprehensive Care for People with STI in 2020 and for their contribution to this work.

\section{AUTHORS' CONTRIBUTIONS}

Ramos MC, Aragon MG, and de Lannoy LH contributed to the manuscript's conception, design, and writing. Ramos MC, Sardinha $\mathrm{JC}$, and Alencar HDR contributed to elaborating the clinical aspects, treatment and surveillance, prevention and control, and critically reviewed the manuscript. All authors approved the final version to be published and are responsible for all aspects of the work, including ensuring its accuracy and integrity.

\section{REFERENCES}

1. Ministério da Saúde (BR). Secretaria de Vigilância em Saúde. Departamento de Doenças de Condições Crônicas e Infecções Sexualmente Transmissíveis. Protocolo clínico e diretrizes terapêuticas para atenção integral às pessoas com infecções sexualmente transmissíveis (IST) [Internet]. Brasília: Ministério da Saúde; 2020 [cited 2020 out 19]. 248 p. Available at: http://www.aids.gov.br/pt-br/ pub/2015/protocolo-clinico-e-diretrizes-terapeuticas-para-atencaointegral-pessoas-com-infeccoes

2. Brasil. Ministério da Saúde. Portaria MS/GM no 42 , de 5 de outubro de 2018. Torna pública a decisão de aprovar o Protocolo Clínico e Diretrizes Terapêuticas para Atenção Integral às Pessoas com Infecções Sexualmente Transmissíveis (IST), no âmbito do Sistema Único de Saúde - SUS [Internet]. Diário Oficial da União, Brasília (DF), 2018 out 8 [cited 2020 jul 31];Seção 1:88. Available from: http://conitec.gov.br/ images/Relatorios/Portaria/2018/Portaria_SCTIE_N42_05_10_2018. pdf

3. Noda AA, Blanco O, Correa C, Pérez L, Kourí V, Rodríguez I. Etiology of genital ulcer disease in male patients attending a sexually transmitted diseases clinic: first assessment in Cuba. Sex Transm Dis [Internet]. 2016 Aug [cited 2020 Oct 19];43(8):494-7. Available from: https://doi. org/10.1097/OLQ.0000000000000470

4. World Health Organization - WHO. Report on global sexually transmitted infection surveillance, 2018 [Internet]. Geneva: World Health Organization; 2018 [cited 2020 Oct 19]. Available from: https://www.who. int/reproductivehealth/publications/stis-surveillance-2018/en/

5. Moherdaui F, Vuylsteke B, Siqueira LF, Santos Júnior MQ, Jardim ML, Brito AM, et al. Validation of national algorithms for the diagnosis of sexually transmitted diseases in Brazil: results from a multicenter study. Sex Transm Infect. 1998 Jun;74(Suppl 1):S38-43.

6. González-Beiras C, Marks MY, Chen C, Roberts S, Mitjà O. Epidemiology of Haemophilus ducreyi infections. Emerg Infect Dis [Internet]. 2016 Jan [cited 2020 Oct 19];22(1):1-8. Available from: https://dx.doi.org/10.3201\%2Feid2201.150425

7. Naveca FG, Sabidó M, Amaral TAP, Veras EA, Contreras Mejía MC, et al. Etiology of genital ulcer disease in a sexually transmitted infection reference center in Manaus, Brazilian Amazon. PLoS One [Internet]. 2013 [cited 2020 Oct 19];8(5):e63953. Available from: https://doi. org/10.1371/journal.pone.0063953

8. Patel R, Kennedy OJ, Clarke E, Geretti A, Nilsen A, Lautenschlager S, et al. 2017 European guidelines for the management of genital herpes. Int J STD AIDS [Internet]. 2017 [cited 2020 Oct 19];28(14):1366-79. Available from: https://doi.org/10.1177/0956462417727194 
9. Workowski KA. Centers for Disease Control and Prevention - CDC. Sexually transmitted diseases treatment guidelines. Clin Infect Dis [Internet]. 2015 [cited 2020 Oct 19];61(Suppl 8):S759-62. Available from: https://doi.org/10.1093/cid/civ7712015

10. Ministério da Saúde (BR). Secretaria de Vigilância em Saúde. Departamento de Doenças de Condições Crônicas e Infecções Sexualmente Transmissíveis. Sífilis | 2019. Bol Epidemiol [Internet]. 2019 out [cited 2020 out 19]; especial. Available from: http://www.aids. gov.br/pt-br/pub/2019/boletim-epidemiologico-sifilis-2019

11. Lautenschlager S, Kemp M, Christensen JJ, Mayans MV, Moi H. 2017 European guideline for the management of cancroid. Int J STD AIDS [Internet]. 2017 Mar [cited 2020 Oct 19];28(4):324-9. Available from: https://doi.org/10.1177/0956462416687913

12. O'Farrell N, Lazaro N. UK National guideline for the management of Chancroid 2014. Int J STD AIDS [Internet]. 2014 Dec [cited 2020 Oct 19];25(14):975-83. Available from: https://doi. org $/ 10.1177 / 0956462414542988$

13. Buder S, Schöfer H, Meyer T, Bremer V, Kohl PK, Skaletz-Rorowski A, Brockmeyer N. Bacterial sexually transmitted infections. J Dtsch Dermatol Ges [Internet]. 2019 Mar [cited 2020 Oct 19];17(3):287-315. Available from: https://doi.org/10.1111/ddg.13804

14. Vries HJC, Barbeyrac B, De Vrieze NHN, Viset JD, White JA, VallMayans M, et al. 2019 European guideline on the management of lymphogranuloma venereum. JEADV [Internet]. 2019 [cited 2020 Oct 19];33:1821-8. Available from: https://doi.org/10.1111/jdv.15729

15. Williamson DA, Chen MY. Emerging and reemerging sexually transmitted infections. N Engl J Med [Internet]. 2020 [cited 2020 Oct 19];382(21):202332. Available from: https://doi.org/10.1056/nejmra190719

16. O'Farrell N, Moi H. 2016 European guideline on donovanosis. Int J STD AIDS [Internet]. 2016 Feb [cited 2020 Oct 19];27(8):605-7. Available from: https://doi.org/10.1177/0956462416633626

17. Garland SM, Steben M. Genital herpes. Best Pract Res Clin Obstet Gynaecol [Internet]. 2014 [cited 2020 Oct 19];28(7):1098-110. Available from: https://doi.org/10.1016/j.bpobgyn.2014.07.015

18. Money D, Steben M. No. 207 - Genital herpes: gynaecological aspects. J Obstet Gynaecol Can [Internet]. 2017 Jul [cited 2020 Oct 19];39(7):e10511. Available from: https://doi.org/10.1016/j.jogc.2017.04.015

19. Kingston M, French P, Higgins S, McQuillan O, Sukthankar A, Stott C, et al. UK national guidelines on the management of syphilis 2015 . Int J STD AIDS [Internet]. 2016 May [cited 2020 Oct 19];27(6):421-46. Available from: https://doi.org/10.1177/0956462415624059

20. Janier M, Hegyi V, Dupin N, Unemo M, Tiplica GS, Potočnik M, et al. 2014 European guideline on the management of syphilis. J Eur Acad Dermatol Venereol [Internet]. 2014 Dec [cited 2020 Oct 19];28(12):158193. Available from: https://doi.org/10.1111/jdv.12734

21. Belda JW, Di Chiacchio N, Criado PR. Tratado de dermatologia. 2. ed. São Paulo: Atheneu; 2015. 2768 p.

22. Stoner BP, Cohen SE. Lymphogranuloma venereum 2015: clinical presentation, diagnosis, and treatment. Clin Infect Dis [Internet]. 2015 Dec [cited 2020 Oct 19];61(Suppl 8):S865-73. Available from: https://doi. org $/ 10.1093 / \mathrm{cid} / \operatorname{civ} 756$

23. Velho PE, Souza EM, Belda Junior W. Donovanosis. Braz J Infect Dis [Internet]. 2008 [cited 2020 Oct 19];12(6):521-5. Available from: https://doi.org/10.1590/s1413-86702008000600015

24. Gabrielson AT, Le TV, Fontenot C, Usta M, Hellstrom WJG. Male genital dermatology: a primer for the sexual medicine physician. Sex Med Rev [Internet]. 2019 Jan [cited 2020 Oct 19];7(1):71-83. Available from: https://doi.org/10.1016/j.sxmr.2018.09.004
25. Wagenlehner FME, Brockmeyer NH, Discher T, Friese K, Wichelhaus TA. The presentation, diagnosis, and treatment of sexually transmitted infections. Dtsch Arztebl Int [Internet]. 2016 [cited 2020 Oct 19];113(12):11-22. Available from: https://doi.org/10.3238/arztebl.2016.0011

26. World Health Organization - WHO. Diagnóstico laboratorial de doenças sexualmente transmissíveis, incluindo o vírus da imunodeficiência humana [Internet]. Brasília: Organização Mundial da Saúde; Ministério da Saúde; 2013 [cited 2020 out 19]. Available from: https://apps.who.int/ iris/bitstream/handle/10665/85343/9789241505840_por.pdf?sequence $=7$

27. Ministério da Saúde (BR). Secretaria de Vigilância em Saúde. Departamento de Vigilância, Prevenção e Controle das Doenças Sexualmente Transmissíveis, HIV/Aids e Hepatites Virais. Manual para o diagnóstico da sífilis [Internet]. Brasília: Ministério da Saúde; 2016 [cited 2020 out 19]. Available from: http://www.aids.gov.br/pt-br/ pub/2016/manual-tecnico-para-diagnostico-da-sifilis

28. White J, O'Farrell N, Daniels D. 2013 UK National guideline for the management of lymphogranuloma venereum. Int J STD AIDS [Internet]. 2013 Jul [cited 2020 Oct 19];24(8):593. Available from: https://doi. org/10.1177/0956462413482811

29. O'Farrell N, Hoosen A, Kingston M. 2018 UK national guideline for the management of donovanosis. Int J STD AIDS [Internet]. 2018 Sep [cited 2020 Oct 19];29(10):946-8. Available from: https://doi. org $/ 10.1177 / 0956462418770319$

30. Prabhakar P, Narayanan P, Deshpande GR, Das A, Neilsen G, Mehendale $\mathrm{S}$, et al. Genital ulcer disease in India: etiologies and performance of current syndrome guidelines. Sex Transm Dis [Internet]. 2012 Nov [cited 2020 Oct 19];39(11):906-10. Available from: https://doi.org/10.1097/ olq. $0 \mathrm{~b} 013 \mathrm{e} 3182663 \mathrm{e} 22$

31. Brasil. Ministério da Saúde. Portaria MS/GM no 1.984, de 12 de setembro de 2014. Define a lista nacional de doenças e agravos de notificação compulsória, na forma do Anexo, a serem monitorados por meio da estratégia de vigilância em unidades sentinelas e suas diretrizes [Internet]. Diário Oficial da União, Brasília (DF), 2014 set 15 [cited 2020 maio 31];Seção 1:59. Available from: http://www.acm.org.br/acm/acamt/ documentos/emfoco/portaria-n-1984-12-09-2014.pdf.

32. Ministério da Saúde (BR). Secretaria de Vigilância em Saúde. Coordenação-Geral de Vigilância das Infecções Sexualmente Transmissíveis. Vigilância epidemiológica das infecções sexualmente transmissíveis no Brasil. Bol Epidemiol [Internet]. 2020 fev [cited 2020 jun 9];51(8):11-5. Available from: https://www.saude.gov.br/images/ pdf/2020/fevereiro/21/Boletim-epidemiologico-SVS-08.pdf.

33. Bazzo ML, Golfetto L, Gaspar PC, Pires AF, Ramos MC, Franchini $\mathrm{M}$, et al. First nationwide antimicrobial susceptibility surveillance for Neisseria gonorrhoeae in Brazil, 2015-16. J Antimicrob Chemother [Internet]. 2018 [cited 2020 Oct 19];73(7):1854-61. Available from: https://doi.org/10.1093/jac/dky090

34. Sehgal VN, Pandhi D, Khurana A. Nonspecific genital ulcers. Clin Dermatol [Internet]. $2014 \mathrm{Feb}$ [cited 2020 Aug 6];32(2):259-74. Available from: https://doi.org/10.1016/j.clindermatol.2013.08.024

35. Patel R, Green J, Clarke E, Seneviratne K, Abbt N, Evans C, et al. 2014 UK national guideline for the management of anogenital herpes. Int J STD AIDS [Internet]. 2015 Oct [cited 2020 Oct 19];26(11):763-76. Available from: https://doi.org/10.1177/0956462415580512

36. Gnann JW, Whitley RJ. Genital herpes. N Engl J Med [Intenet]. 2016 Aug [cited 2020 Oct 19];375:666-74. Available from: https://doi. org/10.1056/NEJMcp1603178

37. Foley E, Clarke E, Beckett VA, Harrison S, Pillai A, FitzGerald M, et al. Management of genital herpes in pregnancy [Internet]. London: BASHH; 2014 [cited 2020 Oct 19]. Available from: https://www.rcog. org.uk/globalassets/documents/guidelines/management-genital-herpes. 
pdf.

38. Govender D, Narddok K, Chetty R. Granuloma inguinale: an usual cause of otitis media and mastoiditis in children. Am J Clin Pathol [Internet]. 1997 Nov [cited 2020 Oct 19];108(5):510-4. Available from: https://doi.org/10.1093/ajcp/108.5.510

39. Scott CW, Harper D, Jason RS. Neonatal granuloma venereum. Am
J Dis Child [Internet]. 1953 Mar [cited 2020 Oct 19];85(3):308-15. Available from: https://doi.org/10.1001/archpedi.1953.02050070320006

40. Ramdial PK, Sing Y, Ramburan A, Naidu TK, Samuel EY, Bagratee JS, et al. Infantile donovanosis presenting as external auditory canal polyps. A diagnostic trap. Am J Dermatopathol [Internet]. 2012 Dec [cited 2020 Oct 19];34(8):818-21. Available from: https://doi.org/10.1097/ DAD.0b013e3182540ccb 